\section{Betie Febriana ${ }^{1}$}

1 Departemen Keperawatan Jiwa, Fakultas Ilmu Keperawatan, Universitas Islam Sultan Agung, Jl. Kaligawe Km.4 Semarang, 50112, Indonesia E-mail: betie.febriana@gmail.com

\title{
Penurunan Kecemasan Remaja Korban Bullying Melalui Terapi Kogitif
}

\section{Info Artikel:}

Masuk : 28 Desember 2016

Revisi : 13 Mei 2017

Diterima : : 20 Mei 2017

DOI Number : 10.18196/ijnp.1255

\section{ABSTRAK}

Bullying menimbulkan dampak negatif bagi remaja, salah satunya adalah kecemasan yang dapat mempengaruhi prestasi belajar. Oleh karena itu dibutuhkan terapi untuk menurunkan kecemasan. Penelitian ini bertujuan untuk mengetahui efektifitas terapi kognitif dalam menurunkan kecemasan remaja korban bullying. Subjek dalam penelitian ini adalah siswa SMA kelas X yang menjadi korban bullying. Desain penelitian yang dipakai adalah True Experimental Pre-Post Test With Control Group dengan jumlah sampel 22 responden dengan teknik simple random sampling. Penelitian ini menggunakan Olweus Bully/Victims Questionare untuk mengetahui siswa yang menjadi korban bullying dan HARS (Hamilton anxietyraing scale) $\left(\mathrm{r}_{\mathrm{xx}}\right.$ $=0,617$ ) untuk mengetahui tingkat kecemasan. Hasil penelitian ini adalah terapi kognitif efektif menurunkan tingkat kecemasan pada remaja korban bullying (nilai $\mathrm{p}=0,002$ ). Temuan lain dalam penelitian ini adalah terdapat perbedaan pertemuan pada responden saat mendapatkan terapi, hal ini bergantung pada jumlah pikiran negatif dan kemampuan responden untuk mengontrol pikiran negatif.

Kata kunci: bullying, kecemasan, terapi kognitif

\section{ABSTRACT}

Bullying causes many negative impacts to the victims, one of them is anxiety. Anxiety influence learning achievement for student. Therefore, it is important to take therapy to reduce anxiety. This study aims to determine the effectiveness of cognitive therapy in reducing anxiety in adolescents' victims of bullying. Subjects in this study were SMA'S students who are victims of bullying. The research design used True Experimental Pre-Post Test With Control Group. Sample was 22 respondents with simple random 


\section{NURSING PRACTICES}

sampling technique. Researchers used Olweus Bully / Victims Questionnaire to identify students who are victims of bullying and HARS (Hamilton anxietyrating scale) $(\mathrm{rxx} "=0.617)$ to identify anxiety before and after therapy. The results of this study was cognitive therapy reduce anxiety level in adolescent's victim of bullying ( $\mathrm{p}$-value=0,002). Another finding in this study, there was a difference of quantitative meetings on respondents when getting therapy, it depends on the number of negative thoughts and the ability of respondents to control negative thoughts.

Keywords: bullying, anxiety, cognitive therapy

\section{PENDAHULUAN}

Kecemasan pada remaja salah satunya diperoleh dari perilaku agresif yang dilakukan oleh teman sebaya. James (2010) mengatakan bahwa Bullying pada umumnya terjadi di sekolah yang termasuk jenis perilaku agresi. Data dari Plan International And Interational Center For Research On Woman (ICRW) bahwa 84\% anak di Indonesia dengan kisaran usia 1217 tahun mengalami bullying, angka ini lebih tinggi dibading negara lain di kawasan Asia.

Seperti yang ditimbulkan oleh agresi, perilaku Bullying juga menimbulkan bahaya, baik mental, fisik, kognitif ataupun emosional yang hal tersebut dilakukan secara sengajaRivers, lan, \& Noret (2012). Pada umumnya, bullying menjadi tradisi sekolah yang dilakukan oleh senior jika tak mengikuti aturan mereka, meskipun banyak juga bullying teman sebaya. Korban bullying biasanya enggan untuk mengadukannya ke pihak lain termasuk orang tua karena kecemasan akan mendapat perlakuan yang lebih buruk lagi. Hal inilah yang membuat tindakan Bullying semakin merajalela jika tidak tertangani dengan tepat.

Beragam dampak buruk yang ditimbulkan oleh bullying. Elmerbrink, Scielzo, \& Campbell (2015) dalam studinya menemukan bahwa bullying dapat memberikan efek kecemasan, berpengaruh pada harga diri, dan mengakibatkan depresi pada korbannya. Studi lain yang dilakukan oleh Kowalski, Robin,\& Limber (2012) menyatakan bahwa kecemasan karena bullying menjadi factor terbesar anak-anak enggan untuk pergi ke sekolah.

Olivarez, Sanchez, \& Lopez (2009) menyebutkan bahwa terdapat tiga aspek dalam kecemasan yaitu, bentuk penghindaran sosial dan rasa tertekan yang dialami secara umum, bentuk penghindaran sosial dan rasa tertekan dalam situasi yang baru atau ketika berhubungan dengan orang baru/orang asing, sertaketakutan terhadap evaluasi negatif dari orang lain. Kecemasan juga menimbulkan beberapa dampak, antara lain remaja dengan tingkat kecemasan yang tinggi memiliki teman yang lebih sedikit, adanya persepsi negatif terhadap diri sendiri, gangguan fungsi sosial, dan mengalami hambatan dalam mengembangkan kemampuan dalam lingkungan masyarakat (Festa \& Ginsburg, 2011; Ling lai, Ye \& Chai, 2008)

Penanganan kecemasan korban bullying harus segera mungkin dilakukan untuk meminimalkan dampak. Terapi yang dapat digunakan untuk mengatasi kecemasan pada korban bullying adalah terapi kognitif. Menurut Gavino (2013), terapi kognitif adalah suatu terapi yang mengidentifikasi pemikiran negatif dan merusak yang mendorong ke arah kecemasan dan depresi yang menetap. Terapi kognitif dapat membantu menghentikan pikiran negatif dan membantu penderita melawannya, terapi ini bertujuan untuk mengubah pikiran negatif menjadi positif, membantu mengendalikan diri (Ingul, Aune, \& Nordahl. (2013). Oleh Karena itu, tujuan daari penelitian ini adalah mengetahui efektivitas terapi kognitif terhadap perubahan kecemasan remaja korban Bullying.

\section{METODE}

Desain Penelitian ini adalah kuantitatif dengan rancangan True Experimental Pre-Post Test With Control Group. Kecemasan sebagai variabel dependendanterapi kognitif sebagai variabel independen. Kuesioner O/weus Bully/Victims digunakanuntuk mengetahui siswa yang menjadi korban bullying dan HARS (Hamilton anxietyraing scale) $\left(r_{x x^{\prime}}=0,617\right)$ untuk mengetahu kecemasan responden.

Terapi kognitif diberikan dalam 3 sesi yaitu sesi 1 Identifikasi pikiran otomatis negatif, sesi 2 Penggunaan 
tanggapan rasional terhadap pikiran otomatis negatif dan sesi 3 adalah manfaat tanggapan rasional terhadap pikiran negative. Terapi dilakukan sebanyak 4-6 kali pertemuan, masing-masing pertemuan dilakukan setiap minggu berkisar 45-60 menit pada masingmasing responden.

Sampel sebanyak 22 responden yang terbagi pada kelompok kontrol dan perlakuan dengan metode simple random sampling. Kelompok perlakuan mendapatkan terapi kognitif sedangkan Kelompok kontrol tanpa terapi. Tempat penelitian di salah satu SMA di Semarang pada siswa kelas X. Analisa bivariat menggunakan Uji Kolmogorov smirnov dan ujimarginal homogeneity. Penelitian ini telah melalui uji etik dengan no 783A.1/ S1/FIK/SA/12/2016 oleh Fakultas IImu Keperawatan Universitas Islam Sultan Agung

Tabel 2 Hasil Uji Beda Harga Diri Remaja Korban Bullying Sebelum Dan Sesudah Diberikan Terapi Kognitif Pada Kelompok Perlakuan

\begin{tabular}{ccccccccc}
\hline \multirow{2}{*}{ Tidak Cemas } & \multicolumn{3}{c}{ Tingkat Kecemasan setelah terapi } & \multirow{2}{*}{ Total } & $p$ \\
\cline { 3 - 6 } & Ringan & Sedang & Berat & Panik & & & 1 \\
Tingkat & Tidak cemas & 0 & 0 & 1 & 0 & 0 & 0 \\
Kecemasan & Ringan & 0 & 0 & 0 & 0 & 0 & 0,02 \\
sebelum terapi & Sedang & 5 & 0 & 2 & 0 & 0 & 7 & 1 \\
& Berat & 1 & 0 & 0 & 0 & 0 & 2 \\
\hline & Panik & 2 & 0 & 0 & 0 & 0 & 11 \\
\hline
\end{tabular}

Tabel 3 Hasil Uji Beda kecemasan Remaja Korban Bullying Sebelum Dan Sesudah Diberikan Terapi Kognitif Pada Kelompok Kontrol

\begin{tabular}{|c|c|c|c|c|c|c|c|c|}
\hline \multirow{2}{*}{\multicolumn{2}{|c|}{ Tidak Cemas }} & \multicolumn{4}{|c|}{ Tingkat Kecemasan setelah terapi } & & \multirow{2}{*}{ Total } & \multirow{2}{*}{$p$} \\
\hline & & Ringan & Sedang & Berat & Panik & & & \\
\hline \multirow{5}{*}{$\begin{array}{c}\text { Tingkat } \\
\text { Kecemasan } \\
\text { sebelum terapi }\end{array}$} & $\begin{array}{c}\text { Tidak } \\
\text { cemas }\end{array}$ & 1 & 1 & 0 & 0 & 0 & 2 & \multirow{6}{*}{0,03} \\
\hline & Ringan & 1 & 0 & 0 & 0 & 0 & 1 & \\
\hline & Sedang & 1 & 1 & 0 & 0 & 0 & 2 & \\
\hline & Berat & 1 & 1 & 0 & 2 & 0 & 4 & \\
\hline & Panik & 1 & 1 & 0 & 0 & 0 & 2 & \\
\hline \multicolumn{2}{|c|}{ Total } & 5 & 4 & 0 & 2 & 0 & 11 & \\
\hline
\end{tabular}

Tabel 4Hasil Uji Beda skor kecemasan Remaja Korban Bullying Sesudah Diberikan Terapi Kognitif Pada Kelompok Perlakuan dan Kontrol

\begin{tabular}{|c|c|c|c|c|c|c|c|c|c|c|c|c|}
\hline & \multicolumn{8}{|c|}{ Harga diri } & & & \multirow[t]{3}{*}{ Total } & \multirow[t]{3}{*}{$p$} \\
\hline & \multicolumn{2}{|c|}{ Tidak cemas } & \multicolumn{2}{|c|}{ Ringan } & \multicolumn{2}{|c|}{ Sedang } & \multicolumn{2}{|c|}{ Berat } & \multicolumn{2}{|l|}{ Panik } & & \\
\hline & $\mathrm{n}$ & $\%$ & $\mathrm{n}$ & $\%$ & $\mathrm{n}$ & $\%$ & $\mathrm{n}$ & $\%$ & $\mathrm{n}$ & $\%$ & & \\
\hline $\begin{array}{c}\text { Tidak diberikan CT } \\
\text { (kontrol) }\end{array}$ & 5 & 45,4 & 4 & 36,4 & 0 & 0 & 2 & 18,2 & 0 & 0 & 11 & 0,02 \\
\hline $\begin{array}{c}\text { Diberikan CT } \\
\text { (perlakuan) }\end{array}$ & 8 & 72,7 & 0 & 0 & 3 & 27,3 & 0 & 0 & 0 & 0 & 11 & \\
\hline
\end{tabular}




\section{NURSING PRACTICES}

HASIL

\section{Karakteristik responden}

Tabel 1 Karakteristik Responden Remaja Korban Bullying.

\begin{tabular}{|c|c|c|c|c|c|}
\hline \multirow[t]{2}{*}{ Variabel } & \multirow[t]{2}{*}{ Kategori } & \multicolumn{2}{|c|}{$\begin{array}{c}\text { Kelompok } \\
\text { kontrol } \\
\mathrm{N}=11\end{array}$} & \multicolumn{2}{|c|}{$\begin{array}{c}\text { Kelompok } \\
\text { Perlakuan } \\
\mathrm{N}=11\end{array}$} \\
\hline & & $\mathbf{N}$ & $\%$ & $\mathbf{N}$ & $\%$ \\
\hline Jenis & Laki-laki & 7 & 63,6 & 3 & 27,3 \\
\hline Kelamin & Perempuan Total & 4 & 36,4 & 8 & 72,7 \\
\hline & & 11 & 100 & 11 & 100 \\
\hline $\begin{array}{l}\text { Pekerjaan } \\
\text { Ayah }\end{array}$ & $\begin{array}{l}\text { Tidak Bekerja } \\
\text { Bekerja } \\
\text { Total }\end{array}$ & $\begin{array}{l}4 \\
7 \\
11\end{array}$ & $\begin{array}{l}36,4 \\
63,4 \\
100\end{array}$ & $\begin{array}{l}1 \\
10 \\
11\end{array}$ & $\begin{array}{l}9,1 \\
90,9 \\
100\end{array}$ \\
\hline $\begin{array}{l}\text { Pekerjaan } \\
\text { Ibu }\end{array}$ & $\begin{array}{l}\text { Tidak Bekerja } \\
\text { Bekerja } \\
\text { Total }\end{array}$ & $\begin{array}{l}0 \\
11 \\
11\end{array}$ & $\begin{array}{l}0 \\
100 \\
100\end{array}$ & $\begin{array}{l}6 \\
5 \\
11\end{array}$ & $\begin{array}{l}54,5 \\
45,5 \\
100\end{array}$ \\
\hline $\begin{array}{l}\text { Pendidikan } \\
\text { Ayah }\end{array}$ & $\begin{array}{l}\text { SD } \\
\text { SMP } \\
\text { SMA } \\
\text { Perguruan Tinggi } \\
\text { Total }\end{array}$ & $\begin{array}{l}1 \\
3 \\
6 \\
1 \\
11\end{array}$ & $\begin{array}{l}9,1 \\
27,3 \\
54,5 \\
9,1 \\
100\end{array}$ & $\begin{array}{l}1 \\
3 \\
5 \\
2 \\
11\end{array}$ & $\begin{array}{l}9,1 \\
27,3 \\
45,5 \\
18,2 \\
100\end{array}$ \\
\hline $\begin{array}{l}\text { Pendidikan } \\
\text { Ibu }\end{array}$ & $\begin{array}{l}\text { SD } \\
\text { SMP } \\
\text { SMA } \\
\text { Perguruan Tinggi } \\
\text { Total }\end{array}$ & $\begin{array}{l}3 \\
4 \\
4 \\
0 \\
11\end{array}$ & $\begin{array}{l}27,3 \\
36,4 \\
36,4 \\
0 \\
100\end{array}$ & $\begin{array}{l}1 \\
6 \\
3 \\
1 \\
11\end{array}$ & $\begin{array}{l}9,1 \\
54,5 \\
27,3 \\
9,1 \\
100\end{array}$ \\
\hline
\end{tabular}

Berdasarkan tabel di atas, diketahui bahwa pada kelompok kontrol sebagian besar laki laki yaitu 7 orang $(63,6 \%)$, sedangkan kelompok perlakuan, sebagian besar berjenis kelamin perempuan sebanyak 8 orang $(72,7 \%)$. Rata-rata orang tua laki laki bekerja dan orang tua perempuan lebih banyak yang di rumah. Pendidikan orang tua pada kedua kelompok paling banyak SMA, sedangkan ibu rata-rata SMP.

\section{Data bivariat}

a. Perbedaan tingkat kecemasan remaja korban bullying sebelum dan sesudah diberikan terapi kognitif pada kelompok perlakuan

Berdasarkan tabel 2 didapatkan bahwa terdapat perubahan kategori kecemasan pada kelompok perlakuan. kecemasan setelah terapi menurun menjadi menjadi tidak cemas pada 8 orang responden, bahkan dari kategori panik menurun menjadi tidak cemas. Beberapa masih berada dalam kategori yang sama tetapi hanya 2 orang saja, walaupun berada dalam kategori yang sama, dari hasil skor kecemasan keduanya menurun sebanyak masing-masing 6 dan 7 poin.

Adapun hasil uji statistik, p-value 0,02 yang berarti Ho ditolak sehingga ada perbedaan kecemasan antara sebelum dan sesudah pemberian terapi kognitif pada kelompok perlakuan.

b. Perbedaan kecemasan remaja korban bullying sebelum dan sesudah diberikan terapi kognitif pada kelompok kontrol

Berdasarkan tabel 3 didapatkan bahwa kecemasan pada responden setelah terapi menjadi 5 responden pada kategori tidak cemas sebelumnya hanya terjadi pada 2 responden. Tidak cemas menjadi cemas ringan pada satu orang

Beberapa responden yang berada pada kategori yang sama antara sebelum dan sesudah terapi rata-rata mengalami peningkatan poin. Adapun hasil ujimarginal homogeneity, p-value 0,03 yang berarti Ho diterima sehingga ada perbedaan harga diri antara sebelum dan sesudah pemberian terapi kognitif pada kelompok kontrol

c. Perbedaan kecemasan remaja korban bullying sesudah diberikan terapi kognitif pada kelompok perlakuan dan kontrol

Berdasarkan hasil ujikolmogorov-smirnov pada tabel 4 didapatkan bahwa nilai $p$ adalah 0,02 ( $p<$ $0,05)$ yang artinya terdapat perbedaan harga diri setelah diberikan terapi pada kelompok kontrol dan perlakuan. Oleh karena itu, dapat disimpulkan bahwa ada pengaruh antara pemberian terapi kognitif dengan kecemasan

\section{PEMBAHASAN}

a. Kecemasan remaja korban bullying sebelum dan sesudah diberikan terapi kognitif pada kelompok perlakuan 
Hasil penelitian menyebutkan bahwa terdapat perbedaaan tingkat kecemasan pada remaja sebelum dan sesudah pemberian terapi kognitif pada kelompok intervensi atau perlakuan. Data menyebutkan bahwa tidak semua responden mengalami perubahan tingkat kecemasan, namun semua responden mengalami penurunan skor kecemasan berkisar antara 6-12 skor.

Penurunan skor mempunyai arti bahwa terjadi perubahan tanda dan gejala ansietas menuju arah yang lebih baik walaupun masih dalam tingkat kecemasan yang sama. Oleh karena itu, dapat digeneralisir bahwa terdapat perubahan kecemasan dari sisi tanda dan gejala setelah kelompok intervensi korban bulliying mendapatkan terapi kognitif.

Perilaku bullying merupakan perilaku berulang berupa intimidasi yang dilakukan oleh satu atau beberapa orang yang menganggap dirinya lebuh kuat daripada korban (James, 2010). Carney dan Merrell (2001) mengidentifikasi bahwa dampak bullying cenderung lebih besar pada depresi dan kecemasan. Dampak jangka pajang berpengaruh pada psikososial perkmbangan tahap berikutnya. Ansietas merupakan efek yang bisa menghasilkan efek domino pada aspek yang lain seperti penurunan prestasi karena remaja akan cenderung menghindar bertemu dengan pelaku sehingga sekolah yang notabene menjadi tempat nyaman untuk belajar berubah menjadi lingkungan yang mengancam bagi korban jika tidak mampu melakukan koping yang baik. Perasaan terancam terus menerus akan mejadi teror tersendiri bagi korban sehingga bisa merambah pada aspek biologis korban (Paul, 2009).

Hal ini bermula dari pikiran negatif yang dimiliki oleh korban seperti bahwa mereka tidak mampu melawan pelaku, bersifat pasif, serta terkadang membenarkan label negatif yang diberikan kepadanya. Pikiran negatif ini timbul karena adanya persepsi yang buruk terkait diri sendiri karena mendapatkan perlakuan buruk yang terus berulang. Beck (1987) menyebutnya sebagai pikiran otomatis negatif, yaitu respon yang bersifat negatif tanpa analisis rasional yang terjadi dengan cepat dengan logika yang keliru.

Terapi kognitif membawa dampak menurunnya tanda dan gejala kecemasan atau ansietas. Power (2010) menggambarkan temuan yang penurunan tanda dan gejala depresi salah satunya adalah ketegangan karena cemas setelah diberikan terapi kognitif. Ini artinya terapi kognitif secara general mampu memberikan perbaikan pada gejala kecemasan. Selain tanda kecemasan umum, terapi ini juga menurunkan pikiran negative, afek sedih, dan penigkatkan afek positif. Hasil ini sejalan dengan penelitian Kristanti bahwa klien gagal ginjal kronik yang mengalami harga diri rendah dan depresi menunjukkan bahwa terapi kognitif dapat menurunkan perasaan harga diri rendah dan menurunkan kondisi depresi salah satunya ansetas.

Eimerbrink, Scielzo, dan Campbell (2015) menyatakan krisis pada korban bullying mengakibatkan perubahan emosi seperti takut, depresi, cemas, tidak berdaya, putus asa. Jika masalah psikosoisla karena krisis ini tidak tertangani maka akan memperburuk kondisi psikososial korban. Oleh karena itu, penting untuk membuat klien mampu meningkatkan kemampuan mengontrol pikiran sehingga dampak yang lebih berat tidak terjadi.

Pemberian psikoterapi pada penelitian ini diharapkan dapat menurunkan kecemasan korban bullying. Perubahan kecemasan pada kelompok perlakuan dengan terapi kognitif menunjukkan hasil yang baik dari kondisi kecemasan sedang menjadi tidak cemas bahkan dari kondisi panic menjadi tidak cemas. Ini artinya penurunan kategori yang sangat signifikan pada kelompok perlakuan. Penurunan kecemasan pada kelompok yang mendapat terapi kognitif karena klien dilatih cara melawan pikiran dan mengontrol pikiran yang menganggu. Klien dengan kecemasan akan mempengaruhi kemampuan kognitif seperti 


\section{NURSING PRACTICES}

konsentrasi menurun, berfikir, serta rentang yang menyempit pada area perhatian (Stuart, 2010).

b. Kecemasan remaja korban bullying pada kelompok kontrol.

Pada kelompok kontrol, terlebih dahulu dilakukan penilaian tingkat kecemasan, setelah itu tidak diberikan intervensi apapun oleh peneliti hingga proses intervensi pada kelompok perlakuan selesai. Setelah 6 minggu, dilakukan pnilaian tingkat kecemasan. Berdasarkan uji analisi marginal homogeneity pada tabel sebelumnya didapatkan nilai $p$ 0, 03 dimana $p>0,05$ yang mempunyai arti ada perbedaan harga diri pada kelompok kontrol sebelum dan sesudah intervensi pada kelompok perlakuan.

Kelompok kontrol pada penelitian ini tidak mendapatkan intervensi terapi kognitif selama penelitian dan hasil yang didapatkan adalah bahwa statistik secara umum menunjukkan adanya penurunan kecemasan. Hal ini cukup menarik utnuk dianalisis. Tanda dan gejala kecemasan yang diperlihatkan oleh responden dalam kelompok kontrol sebelum intervensi antara lain, cemas/ takut jika harus berbicara di depan umum, mudah tersinggung, gelisah, sedih, berdebar jika bertemu teman yang menajdi pelaku. Dapat disimpulkan bahwa tanda dan gejala yang paling banyak dirasakan ada dalam konteks kognisi dan perilaku. Gejala ini sejalan dengan penelitiian Smith dkk. (2008) yang menunjukkan bahwa remaja korban bullying memperlihatkan beberapa gangguan terutama pada perilaku, kognisi, dan afeksi serta konsentrasi.

Menurunnya gejala kecemasan pada kelompok ini dapat terjadi karena proses dari program yang ada di sekolah. Sekolah berbasis islam ini memiliki program spiritual anatara lain Sholat dhuhur berjamaah, membaca asmaul husna sebelum memulai pelajaran setiap pagi, shalawat dan membaca alquran bersama. Aktivitas yang lain adalah setiap jam istirahat selalu diputarkan musik bernuansa islam atau shalawat.Mata pelajaran yang diajarkan pun menggaet mata pelajaran khusus islam seperti fiqih, tarikh, bahasa arab, membaca alquran. Hal ini membawa nuansa tersendiri di sekolah tersebut.

Sekolah dengan program spiritualitas yang baik membawa kebaikan pada siswanya pun pada kelompok kontrol korban bullying. Seperti studi yang dilakukan oleh Sharma, Charak,\& Sharma (2009) Kebangkitan makna dan tujuan membawa kembali harapan dan semangat untuk menghadapi kesulitan hidup. Penelitian tersebut menemukan bahwa untuk setiap kenaikan 10 poin di religiusitas intrinsik seseorang, ada peningkatan $70 \%$ dalam pemulihan dari gejala depresi pasca penyakit fisik.

Studi lain yang ditemukan oleh Torabi dkk. (2016) bahwa pelaksanaan perawatan spiritual oleh perawat dapat mempengaruhi situasi mental remaja dengan kanker dan merupakan metode yang cocok untuk mengurangi kecemasan. Oleh karena itu perlu bagi perawat untuk menggunakan intervensi spiritual selama pelaksanaan asuhan keperawatan yang komprehensif.

c. Kecemasan sesudah diberikan terapi kognitif pada kelompok perlakuan dan kontrol.

Berdasrkan tabel sebelumnya didapatkan data analisis bahwa terapi kognitif memberikan pengaruh pada perubahan tingkat kecemasan remaja korban bullying.

Terapi kognitif dalam penelitian ini bertujuan untuk mengendalikan pikiran negative yang timbul karena perilaku bullying yang mengakibatkan kecemasan atau pikiran buruk lain yang terjadi karena menjadi korban bullying. Pikiran yang mengakibatkan ansietas dapat mengganggu seseorang sehingga berakibat menjadi kurang bahkan tidak produktif. Seperti pengakuan beberapa responden bahwa mereka menjadi enggan ke sekolah karena cemas bertemu dengan pelaku bullying. Hal ini akan mengakibatkan ketidaknyamanan psikologis. Jika terus berlanjut berakibat pada penurunan prestasi yang pada 
akhirnya menghambat perkembangan anak secara kognitif di sekolah, tentu ini akan berpengaruh pada masa depan korban jika tidak tertangani. Oleh karena itu, penting diberikan terapi pengontrolan pikiran negative melalui terapi kognitif.

Pelaksanaan terapi kognitif diharapkan memberikan dampak signifikan pada kemampuan klien yang berkaitan dengan kemampuan koping yang adaptif serta pemecahan masalah. Latihan secara teratur menjadi kunci tercapainya hal tersebut, jika dilakukan terus menerus diharapkan klien akan secara otomatis akan terbiasa memandang suatu peristiwa dari sisi positif.

Kelompok kontrol yang tidak mendapat terapi kognitif memang menunjukkan penurunan kecemasan, tetapi justru ada yang meningkat. Kondisi ini menggambarkan pentingnya intervensi keperawatan jiwa, khususnya psikoterapi untuk membantu klien menurunkan kecemasan dengan peningkatan kemampuan mengontrol pikiran yang tidak menyenangkan. Studi yang dilakukan DeRubeis, Webb, Tang, dan Beck (2010) menemukan bahwa adanya variasi pertemuan terapi kognitif, pelaksanaan berulang ulang pada terapi ini dapat memiliki efek secara biologis. Sementara ini pada penelitian ini, belum ditemukan perubahan kecemasan yang signifikan dari sisi biologis.

Saat terapi berlangsung, masing-masing responden memiliki pertemuan yang berbeda bergantung pada banyaknya pikiran negative yang dimiliki responden serta kemampuan dalam berlatih mengendalikannya. Inilah dua factor yang ditemukan oleh peneliti dalam pelaksanaan terapi kognitif. Sesi yang diberikan sama pada setiap responden yaitu 3 sesi, hanya saja jumlah pertemuan yang berbeda antar mereka. Perbedaan terletak pada sesi ke-2 yaitu tentang latihan mengontrol pikiran negative dimana pada sesi ini masing-masing responden membutuhkan jumlah pertemuan yang berbeda bergantung pada banyaknya pikiran negatif dan kemampuan mengendalikannya.

\section{KESIMPULAN}

Penelitian ini menunjukkan bahwa terdapat pengaruh terapi kognitif terhadap penurunan kecemasan remaja korban bullyingdengan nilai p 0,02. Oleh karena itu terapi kognitif dapat diaplikasikan sebagai terapi untuk mengurangi kecemasan remaja korban bullying. Selanjutnya, perlu dikembangkan penelitian yang mengkolaborasikan terapi kognitif dengan aspek spiritual sebagai salah satu terapi yang dapat digunakan untuk remaja korban bullying

\section{REFERENSI}

Carney, A. G. \& Merrell, K. W. (2001) Perspectives on understanding and preventing an international problem. School Psychology International, 22:364-82.

EImerbrink, Scielzo, \& Campbell. (2015). The Impact of Social and Relational Victimization on Depression, Anxiety, and Loneliness: A Meta-Analytic Review. Journal of Bullying and Social Aggression. 1(1). Issn 2375-5849

Festa, C.C. \& Ginsburg, G.S., (2011).Parental and Peer Predictors of Social anxiety in Youth.

Gavino, M.F. (2013). Group Therapy for adolescent bullying victims (cognitive approach). De La Salle University

Ingul, J.M, Aune, \& Nordahl. (2013). A Randomized Controlled Trial of Individual Cognitive Therapy, Group Cognitive Behaviour Therapy and Attentional Placebo for Adolescent Social Phobia. Psychother Psychosom Journal 2014;83:54-61. DOI: 0.1159/000354672. Diunduh dari http://www.ncbi. nlm.nih.gov/pubmed/24281563

James, A.( 2010). School Bullying. Research Briefing

Kowalski, Robin M., \& Limber, S. P. (2012). Psychological, Physical, and Academic Correlates of CyberBullying and Traditional Bullying. Journal of Adolescent Health, 53 (1), S13-S20. doi: 10.1016/j.jadohealth.2012.09.018

Ling lai, Ye \& Chai. (2008). Bullying in middle scool: an aisan-pasicif regional study. Asia pacific education review. 9 (4) :393-405

Liputan6. (2015). Survey ICRW. Diunduh februari 2016. http://news.liputan6.com

Olivarez, J., Sanchez- Garcia, R., Lopez-Pina, J. (2009). 


\section{NURSING \\ PRACTICES}

The liebowitz social anxiety scale for children and adolescents. Journal of Psicothema. 21 (3)

Power, D. (2010). Emotion-Focused Cognitive Therapy. John Wiley: Oxford Malden

Rivers, Ian, \& Noret, N. (2012).Potential Suicide Ideation and Its Association With Observing Bullying at School. Journal of Adolescent Health, 53(1), S32-S36. doi: 10.1016/j.jadohealth.2012.10.279

Sharma, P., Charak, R., \& Sharma, V. (2009). Contemporary Perspectives on Spirituality and Mental Health. Indian Journal of Psychological Medicine, 31(1), 16-23. http:// doi.org/10.4103/0253-7176.53310

Smith, P. K., Mahdavi, J., Carvalho, M., Fisher, S., Russell, S. and Tippett, N. (2008) CyberBullying: Its nature and impact in secondary school pupils. Journal of Child Psychologyand Psychiatry, 49:376-385.

Stuart, G.W. (2010). Principles and practice of psychiatric nursing. $10^{\text {th }}$ ed. Canada: Mosby, Inc

Torabi F, Sajjadi M, Nourian M, Borumandnia N, \&Shirinabadi FA.(2016). The effects of spiritual care on anxiety in adolescents with cancer. Supportive and Palliative Care in Cancer 2016; in press.http://journals. sbmu.ac.ir/spc/article/view/11007 